\title{
The Application of Internet Technology in Innovation of Teaching Political Theory Course
}

\author{
Xiao Han \\ Wuhan Engineering Institute, Wuhan, Hubei, 430403
}

Keywords: Internet technology; political theory; teaching model, innovation

\begin{abstract}
The innovation of training mode is the focus and hotspot of our current higher education reform. The innovation of practice teaching mode of political theory course is a useful exploration for the innovation of our higher education training mode. To innovate the practical teaching mode of political theory lesson in colleges and universities, it is necessary to define the basic connotation of practical teaching scientifically and establish the goals and principles of practical teaching pattern innovation so as to realize the theoretical teaching. It is an important and effective attempt to carry out the auxiliary teaching of political theory course based on new media technology such as Internet and mobile Internet. The practice teaching of political courses should be based on the background of the Internet to explore the application of Internet technology in the innovation of political theory teaching mode. The classroom teaching is driven by the practice in the class, the classroom teaching is extended with the comprehensive training in the school, and the classroom teaching is expanded by the social practice to achieve the actual effect of the education.
\end{abstract}

\section{Introduction}

In recent years, a lot of discussion and exploration has been made in the teaching of political theory education our current educational mode and teaching method has obtained certain progress, but the current political theory course is still in a primary stage of development. In particular, with the development of information technology, the combination of information technology and political theory teaching has become an opportunity for the development of education in the new period [1]. The teaching of political theory is an important part of the political work in Colleges and universities, and the main position of the political education in Colleges and universities. How to innovate the classroom teaching mode of political theory, give full play to the role of the main channel of the classroom, solve the outstanding contradictions in the current classroom teaching, and improve the teaching quality of political theory course, has become an important issue widely concerned by colleges and universities [2]. It is an important and effective attempt to carry out the auxiliary teaching of political theory course based on new media technology such as Internet and mobile Internet. Let's discuss the problems in the teaching practice of political theory, summarize experience and develop together, improve the teaching quality of political course, and make a due contribution to the construction of colleges and universities [3].

\section{An analysis of the current teaching of political theory}

\subsection{The present situation of political theory course}

The development of our current political theory course is similar to that of the general course teaching. It is through the traditional classroom lectures that we transmit knowledge unilaterally and transfer content monotonously. This leads to teachers' hard work in class, and the effect is not good enough. The monotonous learning way of students leads to the low interest in learning. Due to the common role of both sides, the learning efficiency is low and the quality of learning can not be improved very well. Since the new century, the continuous development of network technology, information technology has gradually added to the teaching of science and technology, caused education reform, and year by year network technology to improve the environment, to a certain 
extent, ease the tension between teachers and students, improve the teaching environment [4]. However, due to the immature technology development and regional differences, information technology is not completely integrated with political theory courses. The current classroom teaching reform and development is relatively slow, far from our desired results.

\subsection{The development direction of the Political Theory Course}

Despite the current political theory course development is fairly good, but this is just the beginning, our classroom teaching reform of the road is very long, we present the development direction of political theory course mainly includes the following aspects:

1) To take effective measures to develop excellent teaching software. Teaching software, as an important auxiliary tool of teaching, plays a great role in classroom teaching. Especially in political theory courses, if teachers blindly talk with their mouths, it is far from enough. Students need more content to enrich their class, not just the old knowledge on the textbook.

2) Strengthen the interaction between teachers and students and increase the activity of class. Only the teacher and the students fully interact to achieve the desired results, to make the teacher more inspirational, students more interested. If there is no communication between teachers and students, then it is possible to teach the teachers and students to the school will be out of touch, the teacher can only follow the prescribed order, the students listen is confused, the effect is not ideal [5].

3) Improve the teaching environment and improve the quality of teaching. Now our living conditions are more and more superior, but our classroom teaching facilities are still old, which leads us to many times because of equipment problems can not be well carried out, which requires our leaders to update and maintain teaching equipment in a timely manner. Only in this way can teachers put their heart and soul on the teaching and improve the quality of teaching.

\section{The necessity of the application of internet technology in the course of political theory}

The development of primary and middle school education is developing rapidly. It is the direction of our current education to strengthen the effectiveness of the teaching of political theory in primary and secondary schools. The combination of Internet technology and political theory course has become a hot issue in educational reform [6]. Now we will explain the necessity of applying Internet technology to political theory course from several aspects:

(1) There are many problems in the traditional political lesson. The classroom form is single. The class depends mainly on the teacher's oral expression and a blackboard, which causes many problems to be transmitted, and all the students receive the same information. Because of the individual differences, the content they can accept is different, which leads to many students' low learning enthusiasm and low learning efficiency.

(2) As a new industry, Internet technology has made good achievements in many fields. Many people want to take a ride, the traditional classroom bigger and quicker, the political theory class is no exception, computer assisted instruction (CAI) and computer network teaching has gradually entered the classroom.

(3) The use of Internet technology in the political theory course is of great advantage and feasibility. First, the use of multimedia platform can effectively increase the ability to improve the performance of teaching information and stimulate students' interest in learning. The two is to use the Internet technology platform to carry out classified teaching and teach students in accordance with their aptitude to meet the needs of the multilevel students. Three, the use of network platform can effectively enhance students' practical ability and cultivate their innovative ability [7]. The most important point is that teachers can monitor students' learning state and learning outcomes at any time, and understand students' situation in time. From above points, we can see that there are many defects in our current teaching. Internet technology can not only make up for this defect, but also provide more help. It is not difficult to see that it is necessary to apply Internet technology in political theory course. The students' evaluation of the effect of the teaching model is shown in figure 1 . 


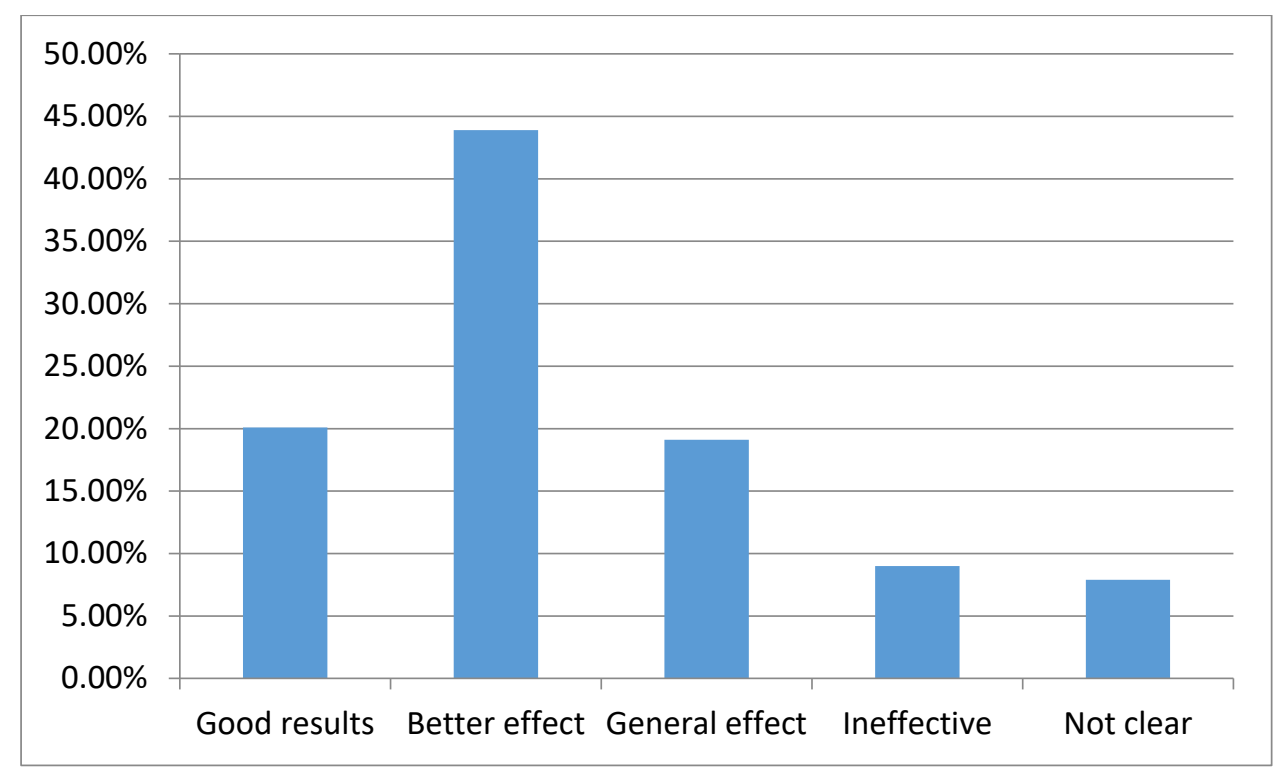

Figure 1. Students' evaluation of the effect of teaching mode

\section{The basic form of innovation mode of practical teaching in political courses in colleges and universities}

The standard of practice teaching in political education is not whether the teaching place is in the society, but whether the teaching content is in the society, that is, whether it is rich in "social practical connotation". It is one-sided to understand the practice teaching of political course as organizing and leading students to leave the classroom, go out of school and carry out activities related to political education [8]. The practice teaching of political course should be the organic unity of classroom teaching and practice teaching. It can be carried out in class and extracurricular. It can be carried out both inside and outside school and can be said and done. In summary, the innovative mode of practical teaching in political courses should include three basic forms: simulated practice teaching, theoretical practice teaching and practical teaching. political theory class practice teaching innovation model is shown in figure 2.

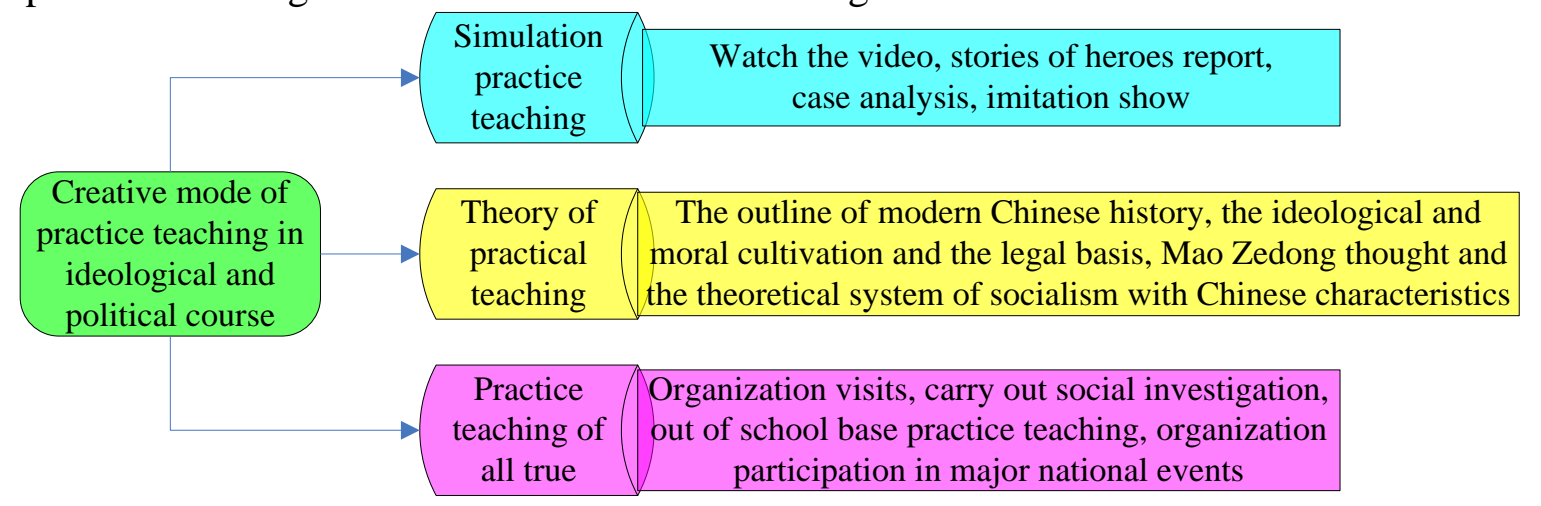

Figure 2. Creative mode of practice teaching in political course

The simulation practice teaching, that is, the practical teaching in the class, is on the first level, and it is the foundation of the whole practice teaching. The teaching goal of this level is to transform the teaching material system of political course to the teaching system, and solve the problem of students' understanding and understanding of knowledge points. The theory applies the practice teaching, that is, the comprehensive training in the school [9]. The comprehensive training in school is the continuation and expansion of the practical teaching in the class. Combined with the classroom theory teaching of political course, relying on the campus practice teaching base and various teaching facilities, we carry out large-scale thematic comprehensive training activities outside campus classroom. At this level, the goal of teaching is to achieve students' acquisition from 
knowledge points to rational thinking and theoretical thinking ability, and to solve the problem of showing knowledge beyond knowledge. All the practice teaching mainly refers to the social practice. The practice of outside school is the point of the practice teaching and the comprehensive training activities within the class, and it is the most important form of practical teaching [10-11]. At this level, the goal of teaching is to transform the knowledge learning and ability training from classroom to campus, to solve the problems of students' professional ethics and political quality and ability.

\section{Reflection on the integration of Internet technology and political theory course}

In recent years, all over the country are looking for appropriate ways to integrate Internet technology with modern classroom teaching, improve classroom interest and student participation, improve classroom teaching quality, and cultivate more professional talents for the future of our country. After a long period of exploration, we have found some problems at the same time, and mainly include the following aspects:

(1) Some teachers have not mastered the Internet technology, and the degree of integration of Internet technology and classroom teaching is not high. They believe that this kind of teaching method compared with the traditional teaching method is not much benefit, but more convenient, to improve the quality of students is not obvious, which mainly exists in some older teachers, in order to solve this problem also takes a long time to do the ideological work of the teacher.

(2) The use of Internet technology to form more teachers and ignore the content of teaching, many teachers after the introduction of the Internet technology, more focus on the processing of Internet technology instead of course record, which leads to the contents of the hollowing out of our teacher. The really technical content is covered by the Internet technology, which can not show the real strength of a teacher. The students are just interested in the moment, the real knowledge is not obtained and this kind of the behaviour is more and more obvious in recent years [12].

(3) Teachers are more focused on the operation of Internet technology rather than communication and communication with students. Since teachers used to interact with students only in face to face with students, they need to take account of multimedia and students at the same time. Some teachers can't perform well in role conversion. They may pay more attention to multimedia and neglect students.

(4) The application mode of Internet technology is monotonous. Many teachers' understanding of multimedia is only in the use of words and pictures. More advanced teachers will join small videos. But these are teachers blindly imitate, but not their own creativity, which makes the teacher's lecture difficult to enter the student's mind, so the desired effect is very difficult to achieve. Based on the above analysis, we can see that the integration of Internet technology and political classroom teaching is still long. We need to further combine the two. Only by sharpening each other can we play a bigger role.

\section{Summary}

As a compulsory course for every student, political theory course is an essential process for the improvement of students' personality and moral quality. Therefore, we must attach great importance to it. Especially in the tide of educational reform, we should hold high the banner of educational reform and take the first line of educational reform. Combining Internet technology with political theory course is the first step for us to try. In the process of reform, we should give full play to students' initiative, enthusiasm, creativity and personal hands-on ability, so as to cultivate students' abilities in many aspects. Only in this way, the reform of our political theory can be carried on without bias. In this paper, we start from the status quo of the political theory course, analyzes the development direction of political theory course, the necessity of the Internet technology combined with the application of Internet technology, as well as in the political theory course, the current political theory course reform has certain reference significance. 


\section{Acknowledgements}

This paper is grateful for the support of the following items: The Education Department of Hubei Province, "12th Five-Year" supported by the special planning: the content of education in higher vocational humanistic quality of selected research and evaluation of the effect of (No.2011A160); Hubei Province Education Science Project: Research on the innovation of higher vocational talent cultivation and teaching reform of political course based on (No.2017GB191).

\section{References}

[1] Bian H, Liu W. Exploration and Practice of the Innovation of the Teaching Method of Ideological and Political Theory Courses in the Use of "Flipped Classroom Mode"[J]. Meitan Higher Education, 2016.

[2] Feng D. On the Innovation and Teaching Effectiveness of "3-M" Teaching Mode Adopted in the Course of Ideological and Political Theory in Colleges_—A case study of the course Introduction to General Principle of Marxism[J]. Social Sciences Journal of Universities in Shanxi, 2017.

[3] Wan L. Innovation Mode of Independent College Ideological and Political Theory Course Explore[J]. Guide of Science \& Education, 2011.

[4] Zhang Y, Zhu Y, Feng H. Approaches to the teaching innovation of university's ideological and political theory course under the new media environment[J]. Journal of Anshan Normal University, 2017.

[5] Dong L I. A Study on the Innovation of the Teaching Mode of the Course of Ideological and Political Theories in Vocational Colleges Under the Background of "MOOC" [J]. Journal of Chongqing Electric Power College, 2016.

[6] Wang C K. The Innovative Application of Subject Representative in the Teaching Management of Ideological and Political Theory Course[J]. Journal of Tangshan Vocational \& Technical College, 2013.

[7] Yang P. Research on Innovation on Teaching Mode of Ideological and political Theoryin Background of MOOC[J]. Journal of Chengdu Aeronautic Polytechnic, 2016.

[8] Ren Y, Marxism S O, University W. Discussion on the Reform and Innovation of the Ideological and Political Theory Course Teaching in Colleges and Universities_- Review of the Second Session of "National Marxism Young Scholars' Luo-Jia Forum” [J]. Studies on Cultural Soft Power, 2017.

[9] Chen X. The Innovation Research on Practice Teaching Mode of Ideological and Political Theory Course[J]. Journal of Yunnan Agricultural University (Social, 2015.

[10] Liu Y. On Patriotic Education Innovation of College Ideological and Political Theory Course under the Condition of New Media[J]. Education \& Teaching Research, 2016.

[11] Liu L L. Innovation and Practice of Ideological and Political Theory Course Teaching in Army Colleges and Universities[J]. World \& Chongqing, 2014.

[12] Liu Z Y. Agricultural Professional College Students' Ideological and Political Theory Course Teaching Mode Innovation__ -I-V-S-S" Mode of Henan Institute of Science and Technology as an Example[J]. Journal of Jilin Teachers Institute of Engineering \& Technology, 2013.

Author's Introduction: Xiao Han, Wuhan Engineering Institute, Wuhan Hubei, 430403,1974.1-, Male, postgraduate, Marxist philosophy, psychology, law and education 